\title{
An overview of emissions of reactive nitrogen compounds from modern light duty vehicles featuring SI engines
}

\begin{abstract}
This paper examines emissions of reactive nitrogen compounds in the exhaust gas flux of vehicles featuring spark ignition (SI) engines. A range of technical, legal and environmental aspects are considered. A discussion of the fundamentals of the phenomenona of emission of these compounds is presented, together with a brief summary of the negative environmental impacts of these gases. Selected data obtained during chassis dynamometer testing at BOSMAL are presented, together with certain important observations presented in the technical literature. The reader is directed to recent publications of note for further information on emissions to the less well known reactive nitrogen compounds, namely $\mathrm{NH}_{3}$ and $\mathrm{N}_{2} \mathrm{O}$. The orders of magnitude of the various reactive nitrogen compounds found in the exhaust gas emitted from SI engines are briefly considered and commented upon. Data are presented on the impact of different fuel types used in SI engines and the reader is directed to various publications on that subject. Finally, important research directions (both current and future) are identified.
\end{abstract}

Key words: spark ignition engines, ammonia, $\mathrm{NO}_{x}$, nitrous oxide, reactive nitrogen compounds, unregulated emissions

\section{O emisji reaktywnych związków azotu w spalinach nowoczesnych pojazdów samochodowych z silnikiem o zapłonie iskrowym}

\begin{abstract}
$W$ artykule zawarto analize problematyki emisji reaktywnych zwiazków azotu w spalinach silników samochodowych o zapłonie iskrowym (ZI). Omówiono przyczyny powstawania tych zwiazków w spalinach silnikowych, ich emisję oraz nagatywny wptyw na środowisko. Przedstawiono wybrane wyniki badań emisji reaktywnych związów azotu w odniesieniu do pojazdów zasilanych paliwami konwencjonalnymi i alternatywnymi, uzyskane w testach emisji na hamowni podwoziowej. Prezentowane wyniki porównano do wyników z tego zakresu opisanych w literaturze. Przedstawiono obecne i przyszłe kierunki badań emisji związów azotu w spalinach silnikowych.

Słowa kluczowe: silniki samochodowe o zapłonie iskrowym, amoniak, tlenki azotu, reaktywne zwiazki azotu, nielimitowane związi szkodliwe
\end{abstract}

\section{RNCs as partially regulated exhaust gas pollutants}

A wide range of compounds are emitted in the exhaust gas of light-duty vehicles featuring internal combustion engines. These vary widely in terms of harmfulness and potential environmental impact, as well as familiarity and notoriety. The 'classic' gaseous pollutants found in this gas flow include $\mathrm{HC}, \mathrm{CO}$ and $\mathrm{NO}$. Methane $\left(\mathrm{CH}_{4}\right)$ and carbon dioxide $\left(\mathrm{CO}_{2}\right)$ have now been included in this category in certain contexts, no doubt linked to the fact that both are important greenhouse gases.

However, it has long been known that other types of compound with potentially deleterious effects are present in vehicular exhaust gas, yet remain unregulated in most (or all) jurisdictions. This group of compounds includes ammonia $\left(\mathrm{NH}_{3}\right)$ and nitrous oxide $\left(\mathrm{N}_{2} \mathrm{O}\right)$; it could also be argued that $\mathrm{NO}$ and $\mathrm{NO}_{2}$ should be included in this category, since at present they are regulated together as $\mathrm{NO}_{\mathrm{x}}\left(\mathrm{NO}+\mathrm{NO}_{2}\right)$, rather than as individual compounds. This paper focuses on these four compounds $\left(\mathrm{NO}, \mathrm{NO}_{2}, \mathrm{NH}_{3}, \mathrm{~N}_{2} \mathrm{O}\right)$, which are termed 'reactive nitrogen compounds' (RNCs; for self-explanatory reasons). Emissions of $\mathrm{NO}_{x}$ from spark ignition engines, while much lower than from compression ignition engines, are non-negligible; the subject has received much attention in the technical literature and in terms of inventions and patents.
The subject of emissions of $\mathrm{NH}_{3}, \mathrm{~N}_{2} \mathrm{O}$ and total RNCs from automotive SI engines has received much less attention in the technical literature, although the first example (a chassis dynamometer study of $\mathrm{NH}_{3}$ emissions) dates from 1967 [1] and there has been something of an upsurge in the number of publications in recent years (e.g. [2-8]).

\section{The environmental impacts of RNCs}

The entire group of compounds which can be termed 'RNCs' is in fact quite broad, including organonitrates $\left(\mathrm{C}_{\mathrm{x}} \mathrm{H}_{\mathrm{y}} \mathrm{N}_{\mathrm{z}}\right)$, nitrates and nitrites; however, such exotic species are not thought to be produced in internal combustion engines (or in their aftertreatment systems) in meaningful quantities. A possible exception to this could be the products of reactions between RNCs and particulate matter, but that phenomenon is beyond the scope of this paper and will not be discussed here. This paper will discuss the RNCs which are of interest in the automotive context $\left(\mathrm{NO}_{\mathrm{x}}, \mathrm{NH}_{3}, \mathrm{~N}_{2} \mathrm{O}\right)$.

Since $\mathrm{NO}_{\mathrm{x}}$ is the most well known of the RNCs, it is also the compound whose environmental impact is best understood, at least by non-specialists; the link between $\mathrm{NO}_{\mathrm{x}}$ and acid rain and photochemical smog has been known for decades. $\mathrm{NO}$ and $\mathrm{NO}_{2}$ differ in terms of reactivity, density, toxicity and even odour and colour, but notwithstanding these differences, it is often most convenient to handle 
both together as $\mathrm{NO}_{\mathrm{x}}$. The environmental impacts of $\mathrm{NO}_{x}$ are wide-ranging and well understood, having a particular impact on the formation of acid rain. However, these gases have zero global warming potential and do not deserve any attention whatsoever in that context.

The impacts of ammonia are also varied and widespread [2]. Like $\mathrm{NO}_{\mathrm{x}}$, the gas is a toxic pollutant. Ammonia also has a characteristic unpleasant odour which is detectable by humans at low concentrations. Ammonia readily reacts with various gases to form 'secondary' particulate matter; many reactions of this type have ammonia as the limiting reagent and so an abundant supply of ammonia ensures that these irreversible reactions proceed rapidly [2]. Such reactions are not merely a chemical curiosity - in Europe up to $90 \%$ of the ambient particulate matter load is formed via reactions between various gases, including ammonia [2, 7]. Ambient ammonia has been identified as a gas of key concern regarding air quality in terms of particulate matter [2, 7].

The effects of $\mathrm{N}_{2} \mathrm{O}$ can be divided into two broad categories: effects as a toxic pollutant and effects as a greenhouse gas. Where concentrations are significantly high, short term exposure can cause feelings of euphoria and reduced consciousness; longer term exposure can result in damage to bone marrow and the peripheral nervous system; harmful effects on pregnant women have also been reported. The gas is heavier than air and can accumulate in sinks, where it readily reacts with other gases. In extreme cases, sufficient concentrations can even create a fire/explosion risk, although it should be stressed that the concentrations present in vehicular exhaust are low and that concentrations at roadside may not be sufficient to cause noticeable effects on humans. However, the other type of problem caused by $\mathrm{N}_{2} \mathrm{O}$ relates to its high global warming potential (GWP): 310 over a 100-year window [9], caused in no small part by an atmospheric lifetime of 120 years [9]. Much less $\mathrm{N}_{2} \mathrm{O}$ than $\mathrm{CO}_{2}$ is emitted, and so the quantity and GWP values cancel each other out to a certain extent. Over the period $1990-2011,5 \%$ of $\mathrm{N}_{2} \mathrm{O}$ emissions in the USA were estimated to be from transport [9]. If stationary combustion sources (generators, incinerators, heating systems, etc) are included, this figure rises to $11 \%$ [9]. It is for these reasons that the US EPA has introduced an emissions limit for $\mathrm{N}_{2} \mathrm{O}$ of $0.01 \mathrm{~g} / \mathrm{mile}$ [10]. In other markets, no emissions limits have been set, although interest is growing.

\section{The formation of RNCs in a SI powertrain}

Where the term 'powertrain' is used, this includes the engine itself as well as the exhaust gas aftertreatment system(s) (hereafter collectively ATS). This is an important point, since the abundances of the various RNCs can be very different depending on whether one is examining the exhaust gas at the engine out location, or downstream of the ATS. The entire group of compounds which can be termed RNCs is in fact quite broad, including organonitrates $\left(\mathrm{C}_{\mathrm{x}} \mathrm{H}_{\mathrm{y}} \mathrm{N}_{\mathrm{z}}\right)$ and nitrates and nitrites; however, such exotic species are not thought to be produced in internal combustion engines or their aftertreatment systems in meaningful quantities. A possible exception to this could be the products of reactions between RNCs and particulate matter, but that phenomenon is beyond the scope of this paper and will not be discussed here. This paper will discuss the RNCs which are of interest in the automotive context $\left(\mathrm{NO}_{x}, \mathrm{NH}_{3}, \mathrm{~N}_{2} \mathrm{O}\right)$.

Regarding the formation of $\mathrm{NO}_{\mathrm{x}}$, the two member compounds ( $\mathrm{NO}$ and $\mathrm{NO}_{2}$ ) are not of equal importance. The formation of NO is SI engines is well understood, being closely related to load, temperature and enrichment. Formation of $\mathrm{NO}_{2}$ within an SI engine is limited, such that the engine out $\mathrm{NO}_{\mathrm{x}}$ flux is dominated by $\mathrm{NO}[8]$ - proportions vary with operating point, but are frequently as high as $\sim 100 \%$. The formation of $\mathrm{NO}_{\mathrm{x}}$ within the cylinder has been the subject of a great number of technical publications and literature reviews and the subject will not be commented on further here. After passing through a TWC which has surpassed its light-off temperature, the concentration of $\mathrm{NO}_{\mathrm{x}}$ in the exhaust gas is generally greatly reduced, (as long as the value of $\lambda$ has not fallen much below 1), again with significantly more $\mathrm{NO}$ than $\mathrm{NO}_{2}$.

For $\mathrm{NH}_{3}$ and $\mathrm{N}_{2} \mathrm{O}$ the situation is very different. Formation of these gases within the engine is very limited. Where emissions are measured from a vehicle (or powertrain) which does not feature a TWC, very low concentrations of these two compounds are detected. Both gases are present in the intake air in very low concentrations, but the combustion reaction occurring within the uncatalysed environment of the cylinder is not conducive to significant formation of either gas.

In a TWC, however, metals specifically chosen for their nitrogen compound selectivity are present, which can act as catalysts for formation of both $\mathrm{NH}_{3}$ and $\mathrm{N}_{2} \mathrm{O}$. A range of chemical reactions which form $\mathrm{NH}_{3}$ and $\mathrm{N}_{2} \mathrm{O}$ are suspected to occur within a TWC under certain conditions. (See $[2,7$, $11,12]$ and references therein for reviews of these processes and reactions.)

To aid understanding of the formation and emissions of RNCs it can be helpful to consider the flux of nitrogen atoms though the powertrain. The key fluxes of nitrogen and nitrogen-based species are shown in Figure 1. For the specific case of ammonia - which has not been studied as extensively as $\mathrm{NO}_{\mathrm{x}}$ - the situation is rather complex, as represented conceptually in Figure 2.

A notable feature of the simplified schematic presented in Figure 2 is the participation of a wide range of species - implying that ammonia can be formed under a range of chemical conditions and relative abundances of other species in the exhaust gas. Multiple reactions may even occur simultaneously, thereby potentially multiplying $\mathrm{NH}_{3}$ emissions.

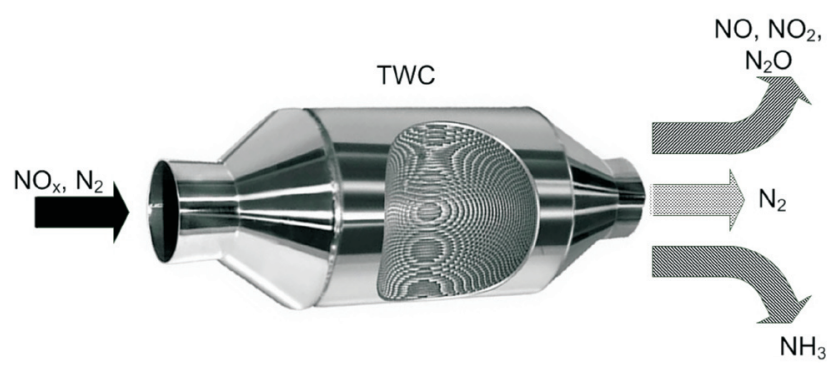

Fig. 1. A schematic of the fluxes of nitrogen and nitrogen-containing chemical species into and out of a TWC. (Note that the outputs include all the RNCs considered in this paper) 


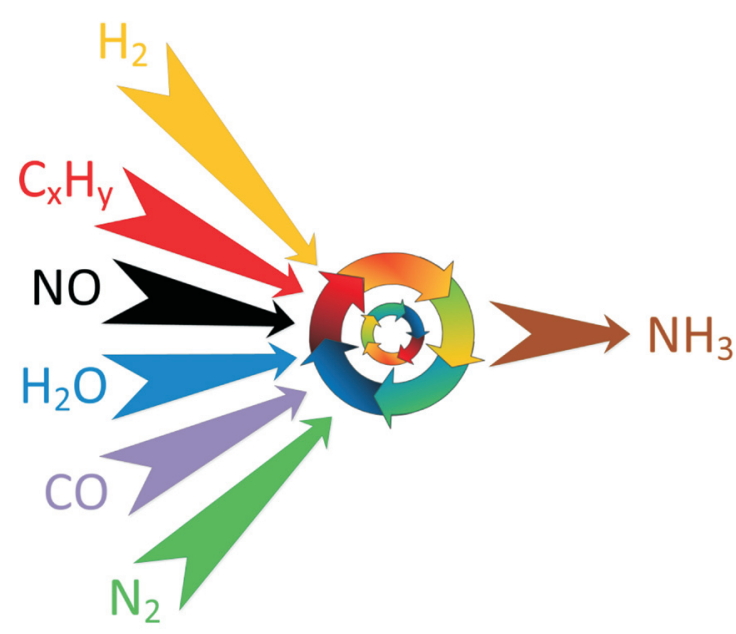

Fig. 2. A wide range of reagents potentially supply a range of reactions which can produce ammonia - research into $\mathrm{NH}_{3}$ formation on a TWC is ongoing

Some simple considerations of the order of magnitude of various RNCs are presented in [8]. A key conclusion of that study was that for the vehicle tested, $\mathrm{NH}_{3}$ made up approaching $20 \%$ of the total RNCs emitted when a passenger car was run over the standard European test cycle, while proportions of $\mathrm{N}_{2} \mathrm{O}$ were much lower.

Another key area of interest is the impact of fuel type (and chemistry) on emissions of RNCs. This subject is explored in section 4.

\section{RNC emissions testing}

Measurement of RNC emissions from vehicles has been performed in three major ways: dynamometer studies performed under laboratory conditions, via on-board analysis of exhaust gases and by remote sensing methods.
Since $\mathrm{NO}_{\mathrm{x}}$ is regulated, laboratory studies tend to follow the mandated measurement procedure for $\mathrm{NO}_{x}$ measurement closely, although other techniques (such as modal analysis of undiluted exhaust gas) are also employed. The other RNCs (and $\mathrm{NO}$ and $\mathrm{NO}_{\mathrm{x}}$ individually) are not regulated, and so a variety of methods are employed by researchers investigating emissions in the laboratory.

On-board measurements and remote sensing studies have their own requirements regarding equipment suitability, sensitivity and portability. BOSMAL has extensive experience in measuring both $\mathrm{NO}_{\mathrm{x}}$ and the unregulated RNCs under laboratory conditions. Work conducted at BOSMAL over the past few years has made use of BOSMAL's advanced climate-controlled emissions testing laboratory (see [13, 14] and Figures 3 and 4), supplemented with a range of analyzers for the quantification of unregulated RNCs (Fig. 5). The majority of these analysers sample raw (undiluted) exhaust gas to produce a concentration value, which can be multiplied by the density of the RNC in question and the measured exhaust flow rate to produce mass-based emissions. Analyzers used by BOSMAL for this type of testing have included units based on Fourier Transform Infra-Red spectroscopy, chemiluminescence and laser diode detector methods, although other options exist (e.g. photoacoustic methods) [2]. Different fuels have also been tested, including standard petrol, petrol-ethanol blends, LPG and CNG.

Some sample results obtained in the aforementioned manner are presented below in Figures 6-11.

The impact of engine type (direct injection/indirect injection) and fuel type on RNC emissions are all important research directions. Other studies have also assessed the impact of usage of alternative fuels on RNC formation (e.g. [7, 8, $12,15])$ - and a very large number of studies have reported $\mathrm{NO}_{x}$ emissions from vehicles running various fuel types.

\section{- 38 SA Automotive Research \& Development Institute Ltd - Euro 5/6 / SULEV Emission Laboratory}

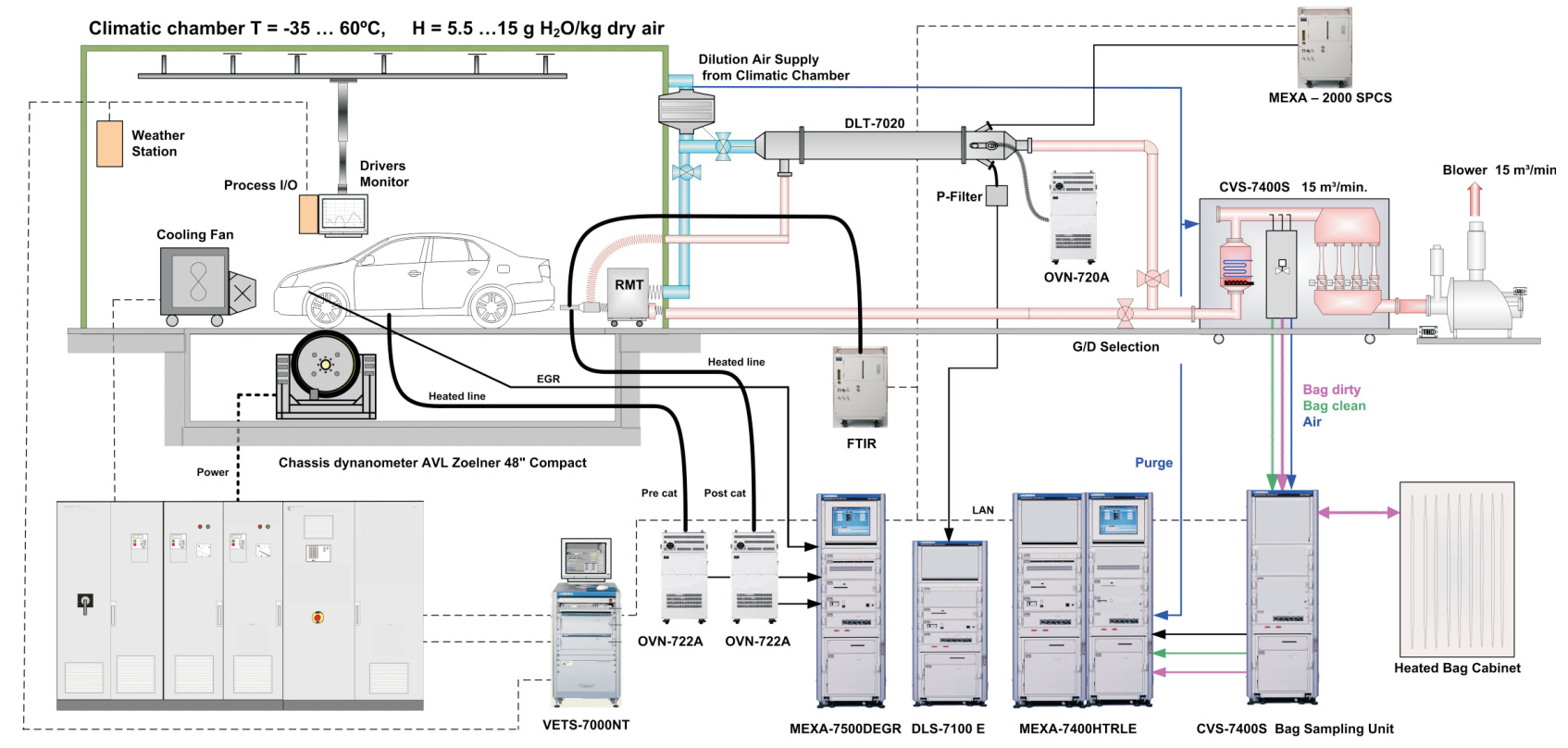

Fig. 3. BOSMAL's exhaust emission laboratory, as used in research into RNC emissions. An FTIR analyser is shown in the system layout, but other analyser types were also employed 
A 2012 study [7] examined the impact of LPG and CNG on $\mathrm{NH}_{3}$ emissions, finding no real change for LPG but a substantial reduction for $\mathrm{CNG}$ (compared to standard petrol). However, such findings are not always observed - for CNG in particular [8].

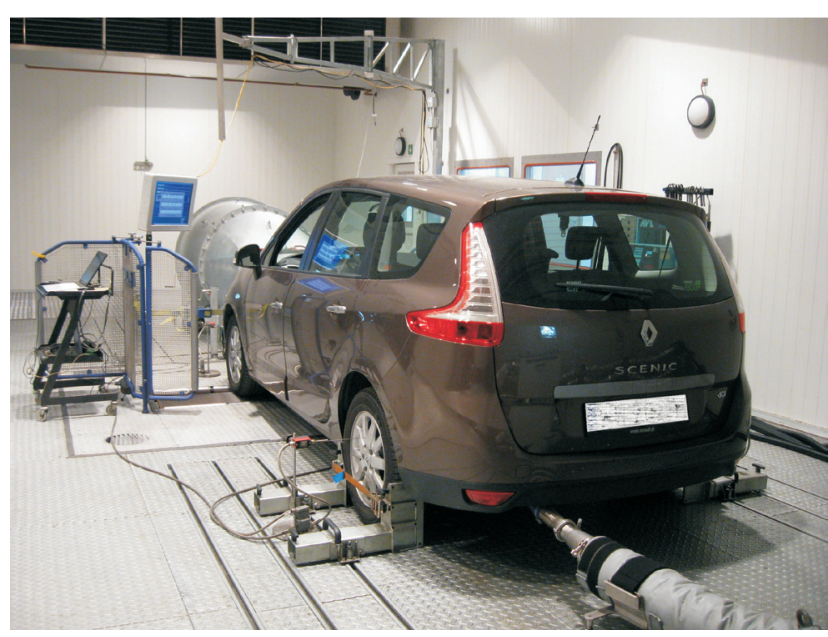

Fig. 4. Interior view of BOSMAL's exhaust emission laboratory, showing a vehicle mounted on the chassis dynamometer, together with the driver's aid (monitor) and the windspeed fan, all within the climatic chamber $\left(-35^{\circ} \mathrm{C}\right.$ to $\left.+60^{\circ} \mathrm{C}\right)$

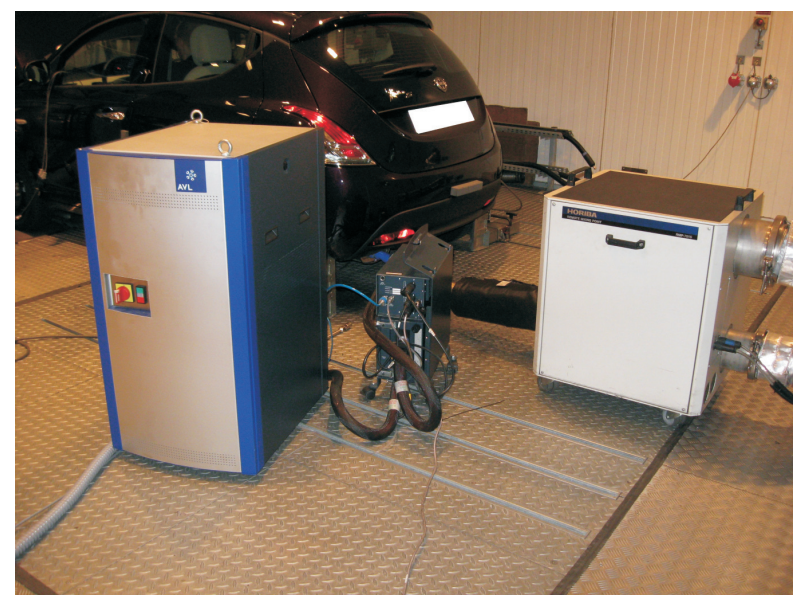

Fig. 5. A specialized automotive emissions analyser for measuring concentrations of $\mathrm{NH}_{3}$ in the exhaust gas of multiple vehicle types

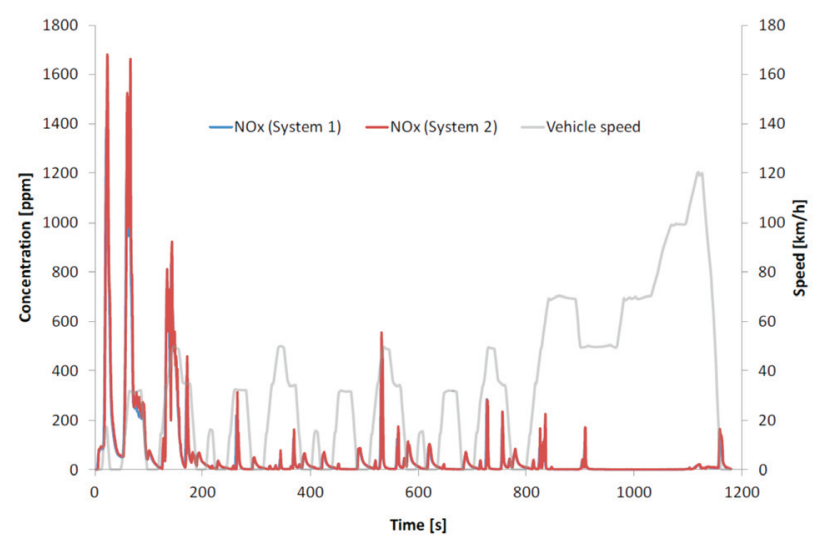

Fig. 6. $\mathrm{NO}_{\mathrm{x}}$ concentration traces measured from the exhaust of a small Euro 5 passenger car using two different analysers, over the NEDC

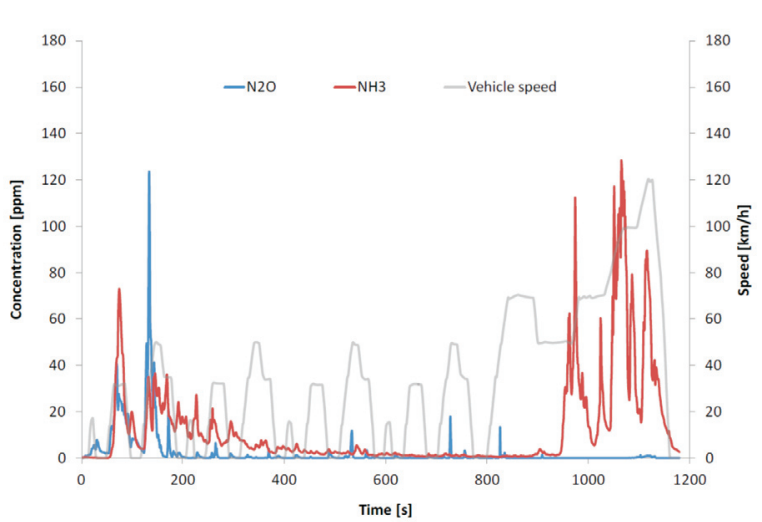

Fig. 7. $\mathrm{N}_{2} \mathrm{O}$ and $\mathrm{NH}_{3}$ concentration traces measured from the exhaust of a small Euro 5 passenger car using two different analysers, over the NEDC

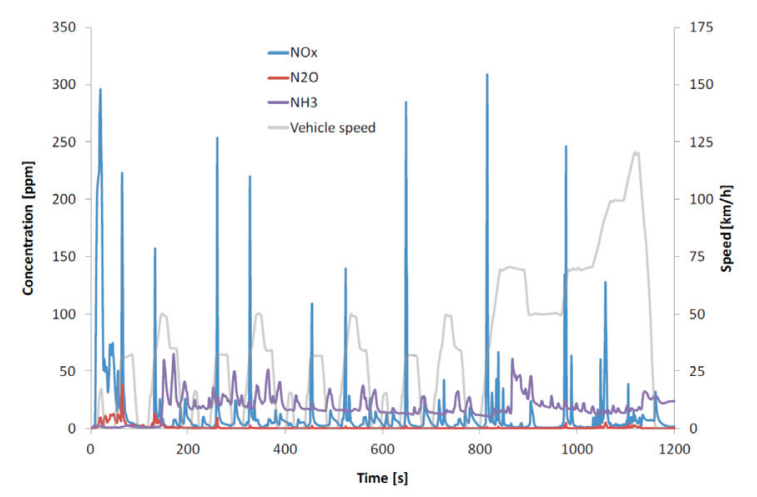

Fig. 8. $\mathrm{NO}_{x}, \mathrm{~N}_{2} \mathrm{O}$ and $\mathrm{NH}_{3}$ concentration traces measuredfrom the exhaust of a medium displacement direct injection Euro 5 passenger car using a laser-based analyser, over the NEDC

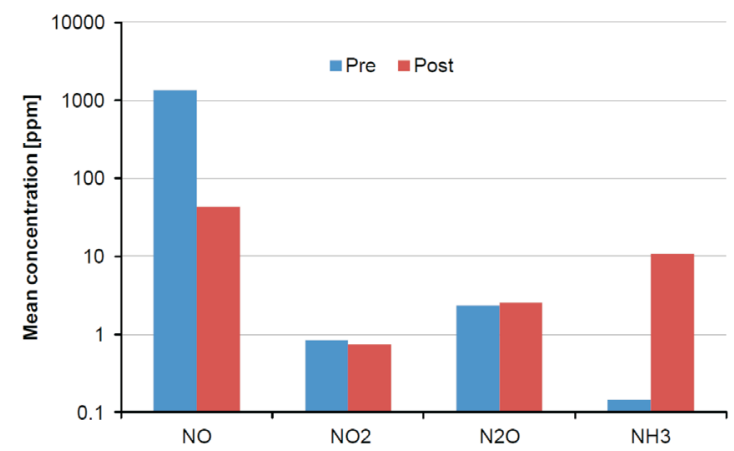

Fig. 9. An analysis of mean RNC concentrations in the exhaust gas (both pre cat and post cat) of a small passenger car obtained over the NEDC (note the $\log 10$ scale)

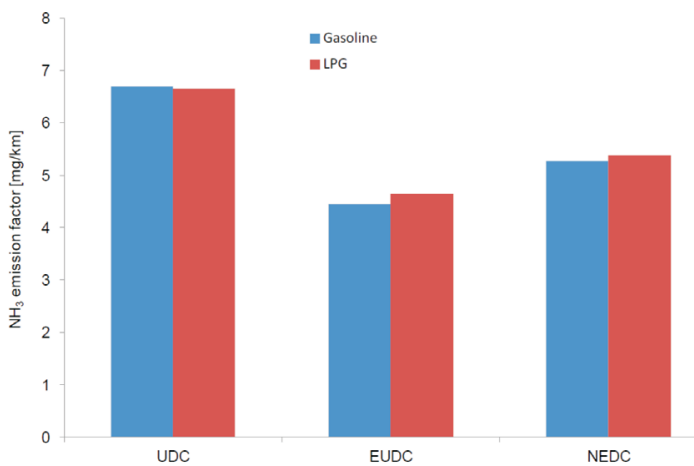

Fig. 10. Mass-based emissions of $\mathrm{NH}_{3}$ from a bifuel passenger car running on petrol and LPG in turn 


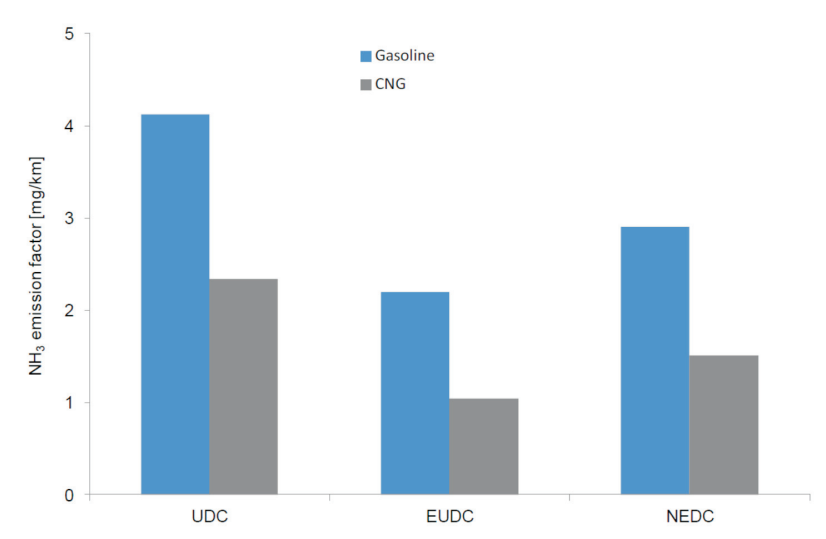

Fig. 11. Mass-based emissions of $\mathrm{NH}_{3}$ from a bifuel passenger car running on petrol and $\mathrm{CNG}$ in turn

In one study [15], mean concentrations of RNCs obtained over the two phases of the NEDC showed varying responses to increased fuel ethanol content; the impact of alternative fuels on RNCs and unregulated emissions in general remains a very important research topic.

Various vehicle eng engine operation metrics have been investigated for their correlations with emissions of RNCs. Abundant discussions of the impact of vehicle duty cycle, temperature etc on emissions of $\mathrm{NO}_{\mathrm{x}}$ are to be found in the literature. For discussion relating to correlations with emissions of $\mathrm{N}_{2} \mathrm{O}$ see $[11,12,16]$ for the case of $\mathrm{NH}_{3}$ see $[2,5,6,8,17]$.

\section{RNC mitigation strategies}

Since TWCs are essential for SI engines to meet the current (and future) stringent exhaust emissions limits, the TWC must feature as a central component in any strategy to limit RNC emissions. As this paper has shown, TWCs are both part of the solution and part of the problem: they are effective in reducing $\mathrm{NO}_{x}$, but the outputs of this process include $\mathrm{NH}_{3}$ and $\mathrm{N}_{2} \mathrm{O}$, in addition to the inert, harmless form of nitrogen $\left(\mathrm{N}_{2}\right)$. Development of advanced SI internal combustion engines must consider aftertreatment as an integral part of the system. The chemical composition, flowrate and temperature of the exhaust gas under real operating conditions should be examined in order to design TWCs which maximize the proportion of $\mathrm{N}_{2}$ they output. This process will necessarily include detailed analysis of current and future fuel types and their influence on the aforementioned factors. Since the nitrogen input is solely in the form of intake air (as liquid hydrocarbon fuels contain negligible nitrogen), reducing the amount of air flowing through the system is an possible strategy for reducing RNC emissions [9]. In practical terms, this means reducing fuel consumption. Indeed, the EPA has identified that strategy as a way of bringing down $\mathrm{N}_{2} \mathrm{O}$ emissions [9]. That being said, certain strategies which aim to reduce fuel consumption (downsizing, boosting, changes to injection timing, cylinder deactivation, etc) can increase engine load, which itself has impacts on RNC formation, the effectiveness of catalytic removal and the resulting exhaust emissions. Efforts to promote cooling and reduce the high temperatures encountered at very high load may also help [2].

\section{Conclusions \& summary}

Emissions of RNCs from modern light duty vehicles with SI engines are noteworthy, even if the numerical values are somewhat low and certain species $\left(\mathrm{NO}_{2}, \mathrm{~N}_{2} \mathrm{O}\right)$ are often present at very low concentrations. However, what all these species have in common is that they are based on one (or two) nitrogen atom(s) and - generally speaking - their concentrations are altered in a TWC - greatly reduced in the case of $\mathrm{NO}$ and massively increased in the case of $\mathrm{NH}_{3}$, with much smaller changes for $\mathrm{NO}_{2}$ and $\mathrm{N}_{2} \mathrm{O}$.

While $\mathrm{NH}_{3}$ and $\mathrm{N}_{2} \mathrm{O}$ remain unregulated, there is not much incentive for ATS and vehicle manufacturers to limit these emissions. Indeed, the various trade-offs which exist between individual RNCs imply that at times higher emissions of $\mathrm{NH}_{3}$ and $\mathrm{N}_{2} \mathrm{O}$ may be desirable from the manufacturer's point of view, as a means of reducing $\mathrm{NO}_{\mathrm{x}}$ emissions [8]. The setting of emissions limits for $\mathrm{N}_{2} \mathrm{O}$ and $\mathrm{NH}_{3}$, or even of a total RNC limit, would radically change this situation and provide strong motivation to maximize exhaust emissions of $\mathrm{N}_{2}$ [7].

As emissions of $\mathrm{NO}_{\mathrm{x}}$ from modern vehicles equipped with SI engines reach very low levels, the magnitude of emissions of other RNCs becomes more significant in comparison, raising questions over the viability of only having a limit for $\mathrm{NO}_{x}$. The introduction of a limit for $\mathrm{N}_{2} \mathrm{O}$ in the USA [10] is surely a sign of increased concern over 'the other RNCs' (i.e. RNCs other than $\mathrm{NO}_{x}$ ), although it should be noted that the $\mathrm{N}_{2} \mathrm{O}$ limit set out in [10] was introduced more out of concern over $\mathrm{N}_{2} \mathrm{O}$ 's GWP than its air quality impacts.

All the RNCs discussed in this paper have negative impacts on air quality. $\mathrm{NO}_{\mathrm{x}}$ is the best known example, and the only regulated compound, but RNCs can be viewed as a harmful chemical continuum - in this context they are an obvious target for emissions reduction in the context of improving air quality. Future automotive emissions legislation (and test procedures) may one day be extended to reflect this fact.

However, at present, there are multiple open questions surrounding sampling and measurement, and so research into test methods and research equipment is arguably as important as emissions data themselves. Other areas which require further investigation are correlates with RNC emissions, trade-off type relationships (see e.g. $[2,7,8]$ ) and the impact of usage of alternative fuels. Within the last category, two cases are of particular interest: testing of ethanol-petrol blends and testing of CNG. Such fuels are currently thought to be promising options for future transportation fuels, and so investigations into emissions as harmful as RNCs are certainly warranted for those fuel types, in order to inform both technical and political decisions regarding usage of alternative fuels.

From the environmental point of view, emissions of such reactive, toxic compounds are a key concern. When coupled with the direct and indirect effects of the RNCs (which range from irritation of mucous membranes to climate forcing effects), it would appear that work on RNC emissions from all sources (including combustion engines) is a research priority with multi-disciplinary dimensions. 


\section{Nomenclature}

\section{$\mathrm{CH}_{4} \quad$ methane}

CNG compressed natural gas

$\mathrm{CO}_{2} \quad$ carbon dioxide

EUDC Extra-Urban Driving Cycle

FTIR Fourier transform infra-red

GWP global warming potential

LPG liquified petrolum gas

$\mathrm{N}_{2} \mathrm{O} \quad$ nitrous oxide

NEDC New European Driving Cycle

$\begin{array}{ll}\mathrm{NH}_{3} & \text { ammonia } \\ \mathrm{NO} & \text { nitrogen oxide } \\ \mathrm{NO}_{2} & \text { nitrogen dioxide } \\ \mathrm{NO}_{x} & \text { oxides of nitrogen } \\ \mathrm{RNC} & \text { reactive nitrogen compounds } \\ \mathrm{SI} & \text { spark ignitron (engine) } \\ \text { TWC } & \text { three-way catalyst } \\ \text { UDC } & \text { Urban Driving Cycle }\end{array}$

\section{Bibliography}

[1] Harkins J., Nicksic S.: Ammonia in Auto Exhaust. Environmental Science and Technology, 1967, 1(9): 751-752, doi: 10.1021/es60009a002.

[2] Bielaczyc P., Swiątek A., Woodburn J.: A technical discussion of the emission of ammonia from SI vehicles fitted with threeway catalysts. Combustion Engines / Silniki Spalinowe, 2011, 1/2011 (144): 63-71, paper PTNSS-2011-SS1-108.

[3] Heeb N., Saxer C.J., Forss A.-M., Brühlmann S.: Correlation of hydrogen, ammonia and nitrogen monoxide (nitric oxide) emissions of gasoline-fueled Euro-3 passenger cars at transient driving. Atmospheric Environment, 2006, 40:3750-3763, doi: 10.1016/j.atmosenv.2006.03.002

[4] Heeb N., Saxer C.J., Forss A.-M., Brühlmann S.: Trends of NO-, NO2-, and NH3-emissions from gasoline-fuelled Euro-3to Euro-4-passenger cars. Atmospheric Environment, 2008, 42:2543-2554, doi: 10.1016/j.atmosenv.2007.12.008

[5] Heeb N., Forss A.-M., Brühlmann S., Lüscherb R., Saxer C.J., Huga P.: Three-way catalyst-induced formation of ammonia - velocity- and acceleration-dependent emission factors. Atmospheric Environment, 2006, 40:5986-5997, doi: 10.1016/j. atmosenv.2005.12.035

[6] Huai T., Durbin T., Younglove T., Scor, G., Barth M., Norbeck J.M.: Vehicle Specific Power Approach to Estimating On-Road NH3 Emissions from Light-Duty Vehicles. Environ. Sci. Technol., 2005, 39:9595-9600. doi: 10.1021/es050120c.

[7] Bielaczyc P., Szczotka A., Swiątek A., Woodburn J.: A Comparison of Ammonia Emission Factors from Light-Duty Vehicles Operating on Gasoline, Liquefied Petroleum Gas (LPG) and Compressed Natural Gas (CNG). SAE Int. J. Fuels Lubr., 2012, 5(2): 751-759, doi:10.4271/2012-01-1095.

[8] Woodburn J., Bielaczyc P., Szczotka A.: Chassis Dynamometer Testing of Ammonia Emissions from Light-Duty SI Vehicles in the Context of Emissions of Reactive Nitrogen Compounds, SAE Technical Paper 2013-01-1346, 2013, doi:10.4271/201301-1346.

[9] United States Environmental Protection Agency - Overview of Greenhouse Gases: $\mathrm{N}_{2} \mathrm{O}$, http://www.epa.gov/climatechange/ ghgemissions/gases/N2O.html

[10] United States Environmental Protection Agency, Light-Duty Vehicle Greenhouse Gas Emission Standards and Corporate

Andrzej Szczotka, DEng. - doctor in Engine Research Department at the BOSMAL Automotive Research \& Development Institute Ltd in Bielsko-Biała.

Dr inż. Andrzej Szczotka-adiunkt w Zakładzie Badań Silników Instytut Badań i Rozwoju Motoryzacji BOSMAL Sp. z o.o., Bielsko-Biała.

e-mail: andrzej.szczotka@bosmal.com.pl
Average Fuel Economy Standards; Final Rule, Federal Register / Vol. 75, No. 88, 2010

[11] Lipman T.E., Delucchi M.A.: Emissions of Nitrous Oxide and Methane from Conventional and Alternative Fuel Motor Vehicles, Climatic Change, 53/4, 2002, doi: 10.1023/ A:1015235211266

[12] Borsari V., de Assunçã, J.: Nitrous oxide emissions from gasohol, ethanol and CNG light duty vehicles 2012, doi: 10.1007/ s10584-011-0203-9

[13] Bielaczyc P., Szczotka A., Woodburn J.: Development of vehicle exhaust emission testing methods - BOSMAL's new emission testing laboratory. Combustion Engines / Silniki Spalinowe, 2011, 144:3-12, paper PTNSS-2011-SS1-101.

[14] Bielaczyc P., Pajdowski P., Szczotka A., Woodburn, J.: Development of automotive emissions testing equipment and test methods in response to legislative, technical and commercial requirements, Combustion Engines / Silniki Spalinowe, 1/2013, 28-41, paper PTNSS-2013-103.

[15] Bielaczyc P., Klimkiewicz D., Pajdowski P., Szczotka A., Woodburn, J.: An examination of the effect of ethanol-gasoline blends' physicochemical properties on emissions from a lightduty spark ignition engine, Fuel Processing Technology, 107, 50-63 2012, doi:10.1016/j.fuproc.2012.07.030.

[16] Graham L.A., Belisle S.L., Rieger P.: Nitrous oxide emissions from light duty vehicles, Atmospheric Environment, 43 20312044, 2009, doi: 10.1016/j.atmosenv.2009.01.002.

[17] Bielaczyc P., Swiątek A., Woodburn J.: Investigations of Ammonia Emissions from Euro 5 Passenger Cars Over a Legislative Driving Cycle, Lecture Notes in Electrical Engineering Volume 189, 671-685, 2013, doi: 10.1007/978-3-642-33841-0_52.

Piotr Bielaczyc, DEng. - head of the Engine Research Department, BOSMAL Automotive Research and Development Institute Ltd in Bielsko-Biała.

Dr inż. Piotr Bielaczyc - kierownik Zakładu Badań Silników, Instytut Badań i Rozwoju Motoryzacji BOSMAL Sp. z o.o., Bielsko-Biała.

e-mail:piotr.bielaczyc@bosmal.com.pl
Joseph Woodburn, MSci. - researcher at the Engine Research Department, BOSMALAutomotive Research and Development Institute Ltd in Bielsko-Biała.

Mgr inż. Joseph Woodburn - inżynier ds. badań w Zakładzie Badań Silników, Instytut Badań i Rozwoju Motoryzacji BOSMAL Sp. z o.o., Bielsko-Biała. e-mail: joseph.woodburn@bosmal.com.pl
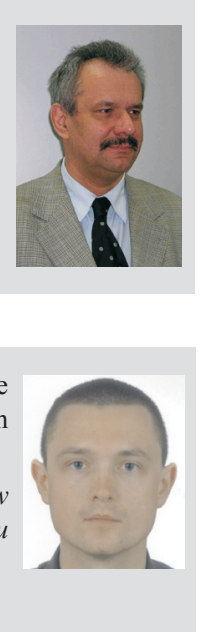